\title{
The role of aptitude in the failure or success of foreign language learning
}

\author{
Laura Furcsa \\ Eszterházy Károly Egyetem
}

\section{Introduction}

One of the major challenges in language pedagogy is the explanation of different levels of success. A huge number of studies have looked at how different variables contribute to the success of language learning. Therefore the scope of this study was restricted to a single cognitive variable by focusing attention on language learning aptitude. Accordingly recent studies of unsuccessful learners are reviewed from this point of view as well as language learners' characteristics and theories related to aptitude are discussed. This section is followed by the investigation of the role of aptitude in empirical studies.

\section{Learners' characteristics influencing success}

There are several factors which are considered to have an influential role in the lack of success in language learning. Larsen-Freeman and Long (1991) listed the following factors: age, language aptitude, social-psychological factors, personality, hemisphere specialization, and learning strategies. In addition to these individual variables, native language variables, input variables, and instructional variables are also mentioned. Gardner and MacIntyre (1992) gave a more systematic classification of these variables, which they group into three broad categories:

1. Cognitive Variables: intelligence, language aptitude, language learning strategies, previous language training and experience

2. Affective Variables: attitude, motivation, language anxiety, feelings of self-confidence about language, personality attributes, learning styles

3. Miscellaneous: age, socio-cultural experiences (with either cognitive or affective implications). 
In their schematic representation of the socio-educational model of second language acquisite socioion (Gardner and MacIntyre, 1992) four major parts are distinguished: socio-cultural milieu, individual differences, language acquisition contexts, and language outcomes. In the model, cultural beliefs in socio-cultural milieu seem to have the most influential role in determining the factors that have an effect on language learning. In their analysis, language aptitude and intelligence are grouped together, although it is stated that they are two different but related concepts.

\section{Conceptualisations of language aptitude}

The theory of aptitude was actively researched in the 1920s and 1930s and the first prognostic tests were constructed at that time. However, the glorious age/age of glory was the 1960s. The research of language aptitude was dominated by an American psychologist, J. B. Carroll and therefore, it is worth starting the conceptualisation of language aptitude with his definition:

Aptitude as a concept corresponds to the notion that in approaching a particular learning task or program, the individual may be thought of as possessing some current state of capability of learning that task - if the individual is motivated, and has the opportunity of doing so. That capability is presumed to depend on some combination of more or less enduring characteristics of the individual.

(Carroll, 1981.p. 84)

According to Carroll (1981), foreign language aptitude consists of four independent abilities: phonetic coding ability (the ability to code and memorise auditory material), grammatical sensitivity (the ability to handle grammar), rote learning ability (rote memory) and inductive language ability (the ability to infer rules and patterns from new linguistic content). Language aptitude is assessed in terms of these abilities that facilitate the acquisition of linguistic material. The most famous test of language aptitude is Carroll and Sapon's Modern Language Aptitude Test, which consists of five subtests (Number Learning, Phonetic Script, Spelling Cues, Words in Sentences, Paired Associates), which are supposed to assess the four different components of language aptitude (Carroll and Sapon, 1959). Another language aptitude test was published by Pimsleur (1966), which 
is very similar to MLAT, but it assesses motivation as a separate factor in the test.

After Carroll's influential work (1981), the study of aptitude became a marginal field within language teaching. Dörnyei and Skehan (2002) list two reasons for this. On the one hand, aptitude is of anti-egalitarian and undemocratic nature differentiating disadvantaged learners. On the other hand, Krashen (1981) argues that aptitude relates only to learning, while aptitude is only relevant for instructed context and not for acquisition. He pointed out that the MLAT only assesses the kind of skills which are associated with formal study. This is the reason why aptitude was neglected in the communicative era. Research concentrated mainly on other individual differences influencing success. Attention focused on affective variables (for example, attitude, motivation, anxiety, personality type) and the role of cognitive style and learning strategies. Aptitude was reinterpreted and linked with other fields of second language acquisition research in the 1990s.

There are two more features of language aptitude which should be mentioned. Language aptitude tests predict only the rate of learning a foreign language, not the ability or inability to learn it, as it is not an absolute measure. Gardner and MacIntyre (1992) viewed language aptitude as a positive transfer, a type of 'cognitive sponge'. If the ability of language aptitude is stronger in the learner, the language skill will be acquired quickly. Carroll (1981) stated that language aptitude is stable and it is difficult to alter it through training. Ottó (1996) emphasised that language aptitude is not related to former learning experience, and tests measure aptitude at zero foreign language proficiency, therefore aptitude tests are written in the learner's mother tongue. Moreover, no substantial connection was found between language aptitude and learning disabilities, as there were no significant differences between the scores of low-achieving students without learning disabilities and students categorized as learning disabled (Sparks, 2016). Graena and Long (2012) examined the connection of aptitude and age, and their results suggested that early language education lead to the development of language aptitude. However, in the case of older learners, aptitude was found to play an important role for native-like pronunciation. 


\section{Concepts of successful language learners}

Despite the fact that aptitude correlates with achievement, it is not investigated in most studies of successful language learners. Wesche (1981) gave clear evidence of how useful it is to classify learners according to their cognitive abilities. The students were streamed in three groups on the basis of their aptitude sub-test scores, one with high memory ability, one with high analytic ability, and one with matched abilities. The training methods were tailored to the participants' abilities: the audiolingual method to the group of high memory ability and a more analytic method to the other group. Appropriate instruction resulted in higher achievement in the involved students' foreign language learning. Aptitude is only one of the learner factors which influences language learning success. Other learner factors are just as influential as aptitude. With the information that could be gained about learners' strengths and weaknesses from language aptitude tests, language courses are more likely to meet the learners' needs and consequently, they may be more effective.

Ottó (1996) also recommended the selection of language learners according to aptitude test scores, which could reduce the number of "failures". Furthermore, aptitude test results could help the learner to identify the areas where he/she has difficulties. He gave practical ideas on how to encourage learners to take advantage of their strengths, for example a learner with high memory and low analytic ability scores should rely rather on rote learning and learning grammar rules by using flash-cards.

The characteristics of good language learners are described in the model of Naiman, Frohlich, Todesco and Stern (1978). There are three independent causative variables which influence learning and outcome: teaching, the learner, and the context. They are divided into subdivisions, and intelligence and aptitude are mentioned as learner characteristics. Unfortunately, in this study these factors were not measured because of lack of time and they wanted to concentrate on factors which were neglected by other researchers, and for this reason no measures of intelligence and language aptitude were given. Naiman, Frohlich, Todesco and Stern stated that "we are unable to speculate how the results of factors such as I.Q. and aptitude would have compared with the measures of personality characteristics, cognitive style, and attitude in predicting success on the criterion measures" (1978, p. 145).

Sparks, Artzer, Ganschow, Siebenhar, Plageman and Patton (1998) described two studies, in which the effect of differences in native language 
skills and foreign-language aptitude to foreign-language proficiency are investigated. They found that the performance on native-language phonological and orthographic measures distinguished low and high proficiency learners. Successful and unsuccessful language learners show evidence of significant differences in their native-language phonological and orthographic skills. However, the best predictors of future success in foreign language (i.e. the end-of-year grade) were ENG 8 (the factors which showed success in an English course) and MLAT F (the performance on the language aptitude test). In both studies, MLAT scores correlated higher with foreign-language proficiency than any of the native-language measures or foreign-language grades. In consequence, they proposed that similar to other subject areas (e.g. Maths) foreign language learning occurs on a continuum of excellent to very poor skill.

Sparks et al. (1998) reacted also to the criticism of foreign language educators that aptitude tests focus mainly on analytical skills and not on communicative skills. They stated that MLAT also assesses skills needed in communication because students with high levels of both oral and written and both expressive and receptive proficiency in a foreign language attained a significantly higher score on the MLAT.

In recent studies, the ethical use of MLAT has been addressed from the point of view of learning disability (Sparks, 2016), although the aim of creating this test was not specifically to measure this factor. Reed and Stansfield (2004) reviewed the ethics of applying the MLAT for identifying and diagnosing students participating in secondary and tertiary education. They raised their concerns about exempting students from foreign language education based on the results achieved on the MLAT.

\section{Qualitative studies on unsuccessful learners}

In most of the studies that examined learner differences, a quantitative approach was adopted. In recent years, however, researchers have called for qualitative investigative methods in the research of influential variables believed to be responsible for the differences between successful and unsuccessful language learners.

Gan, Humphreys and Hamp-Lyons (2004) investigated three learner difference variables (attitudes, motivation, and strategies) from an ethnographic perspective. They gained information from successful and unsuccessful Chinese learners of English through interviews, diaries and e-mail 
correspondence. The variable of language aptitude was not included in the study due to methodological constraints, although the authors stated it is a potentially important learner difference variable. Also cognitive learner differences were included when investigating concepts of cognitive learning processes (strategies). This study underlines the importance of differences in attitudes and in self-management between successful and unsuccessful students.

In other qualitative studies, language aptitude is not measured with the help of aptitude tests. Instead, the learners' beliefs about their own aptitude and the role of inaptitude in their failure to learn a foreign language are investigated. The case study of Albert (2004) described the problem of an unsuccessful learner concentrating on beliefs about language learning. A belief that some people are not or less able to learn a foreign language or are convinced that they have no language aptitude may lead to negative expectations of the student and can be a really serious impediment in language learning. The questionnaire she applied is based on Horwitz (1987), which was developed to evaluate language learners' opinions and beliefs on a variety of issues related to language learning. One part of the Likertscale items focuses on the existence of foreign language aptitude.

In the structured interview, the respondent of Albert (2004, p. 55) is also confronted with statements, like "Some people are born with a special ability for learning a foreign language". He states that he had difficulties in phonetic coding when talking about the method of suggestopedia. He mentions other problems which are in connection with aptitude. He thinks that an important factor in successful language learning is the analytic ability to understand the structure and the grammar of a language. He is convinced that gifted people can learn a language much faster and they can better cope with fewer words. However, it is questionable to what extent the inaptitude of the subject has contributed to his low level of success. His beliefs about his inaptitude may be based on real experience, it may have been worth trying a language aptitude test with the subject to have more objective measures.

Albert's findings (2004) are similar to the results of Wenden (1987). She investigated insights and recommendations from second language learners from the point of view of how to be a successful learner. In the group of influential personal factors three factors were mentioned by the learners: feelings, language aptitude and self-concept. Aptitude was mentioned by only two learners out of 14 showing that the participating learners did not really think it is a crucial factor in language learning. 
The qualitative study of Nikolov (2001) investigated the effect of different variables on different levels of proficiency in foreign language learning. The paper explored why young adults did not succeed in achieving even a basic level of foreign language competence. The structured interviews concentrated on foreign language learning experiences, attitudes and motivations.

As far as language aptitude is concerned, the interview included questions about what makes language learners successful. The participants believed that besides persistence, hard work, motivation and enthusiasm, aptitude is crucial for success. As for their self-assessed aptitude, they rated themselves as average, and 35 (out of 94) stated they had low aptitude. In their interpretations, aptitude is related to good memory, learning fast and easily, being fond of translation, quick memorisation of words, or understanding grammar easily. These associations refer to several components of language aptitude. Good memory seems to be the critical factor which is present in the rote learning ability (rote memory) component of language aptitude. Grammatical sensitivity and inductive language learning ability can also be associated with the above-mentioned factors. The phonetic component, which is considered to have a significant role, is not mentioned at all among the vital internal factors contributing to success.

A number of participants emphasised that their aptitude varied for different target languages, which contradicts the assumption that language aptitude is not related to former learning experiences. Respondents probably mean different attitudes towards languages and cultures by different target language aptitude. One of the respondents even questioned the existence of language aptitude. These findings show that unsuccessful learners do not regard aptitude as a decisive factor in foreign language learning, but they emphasised other related behavioural, affective and cognitive factors. As their language proficiency was considered to be similarly low, this fact reinforces again the previous statement that they do not consider aptitude as the best predictor of success.

\section{Conclusions}

In recent years, foreign language acquisition research has concentrated on other variables (first of all attitude, motivation, anxiety and learning strategies) rather than language learning aptitude when attempting to explain the presence of individual differences in foreign language learning. Research makes it 
clear that in the long run language aptitude is probably the single best predictor of achievement in a second language (Gardner and MacIntyre, 1992). More research is needed to determine whether language aptitude is an innate ability and how far it can be trained so as to facilitate successful second language learning outcomes.

\section{References}

Albert, Á. (2004): Az örök próbálkozó esete: a nyelvtanulási sikertelenség vizsgálata. In: Kontráné Hegybíró E. és Kormos J. (szerk.): A nyelvtanuló 4962). Okker Kft, Budapest.

Carroll, J. B., and Sapon, S. (1959): Modern Language Aptitude Test (MLAT). Psychological Corporation, San Antonio, CA.

Carroll, J. B. (1981): Twenty-five years of research on foreign language aptitude. In: K. C Diller (ed.): Individual differences and universals in language learning aptitude. Newbury House, Rowley, MA. 83-118.

Dörnyei, Z., and Skehan, P. (2002): Individual differences in second language learning. In: C. J. Doughty, and M. H. Long (eds.). Handbook of second language acquisition. Blackwell, Oxford. 589-630.

Gan, Z., Humphreys, G., and Hamp-Lyons L. (2004): Understanding successful and unsuccessful EFL students in Chinese Universities. Modern Language Journal, 88. 229-244.

Gardner, R. C., and MacIntyre, P.D. (1992): A student's contributions to second language learning. Part I: Cognitive variables. Language Teaching, 25. 211220.

Granena, G., and Long, M. H. (2012): Age of onset, length of residence, language aptitude, and ultimate L2 attainment in three linguistic domains. Second Language Research, 29. 311-343.

Krashen, S. (1981): Aptitude and attitude in relation to second language acquisition and learning. In: K. C Diller (ed.): Individual differences and universals in language learning aptitude. Newbury House, Rowley, Mass.

Larsen-Freeman, D., and Long, M. (1991): Introduction to Second Language Acquisition Research. Longman, New York, NY.

Nikolov, M. (2001): A study of unsuccessful language learners. In: Z. Dörnyei and R. Schmidt (Eds.), Motivation and second language acquisition. University of Hawai'i Press, Honolulu, HI. 149-169.

Ottó, I. (1996): Language aptitude testing: Unveiling the mystery. NovELTy, 3. 6-20. 
Pimsleur, P. (1966): Pimsleur Language Aptitude Battery. Harcourt Brace Jovanovitch, New York, NY.

Sparks, R., Artzer M., Ganschow L., Siebenhar D., Plageman M., and Patton J. (1998): Differences in native-language skills, foreign- language aptitude, and foreign-language grades among high-, average-, and low-proficiency foreign-language learners: two studies. Language Testing, 15. 181-216.

Sparks, R., and Ganschow, L. (2001): Aptitude for learning a foreign language. In: M. McGroarty (ed). Annual Review of Applied Linguistics. 21. 90-111. Cambridge University Press, Cambridge.

Sparks, R. (2016): Myths About Foreign Language Learning and Learning Disabilities. Foreign Language Annals, 49. 252-270.

Wesche, M. (1981): Language aptitude measures in streaming, matching students with methods, and diagnosis of learning problems. In: K. C Diller (ed.): Individual differences and universals in language learning aptitude. Newbury House, Rowley, MA. 119-139.

\begin{abstract}
This paper investigates the role of language aptitude as a cognitive variable in the success or failure of foreign language learning. Recent studies of unsuccessful learners are discussed from this point of view, and a brief reference is made to the different conceptualizations of language aptitude. It is followed by the discussion of the role of aptitude in empirical qualitative studies as in recent years, researchers have called for qualitative investigative methods in the investigation of influential variables believed to be responsible for the differences between successful and unsuccessful language learners.
\end{abstract}

